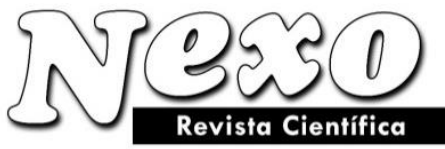

ISSN-E 1995-9516

Universidad Nacional de Ingeniería COPYRIGHT @ (UNI). TODOS LOS DERECHOS RESERVADOS http://revistas.uni.edu.ni/index.php/Nexo https://doi.org/10.5377/nexo.v34i02.11626

Vol. 34, No. 02, pp. 1008-1020M/Junio 2021

\title{
Corrosion resistance of urtites and urtite-based concretes
}

\section{Resistencia a la corrosión de urtitas y concreto basado en urtita}

\author{
Tatyana P. Belogurova ${ }^{1, *}$, Yuriy N. Neradovskiy, Svetlana V. Bastrygina \\ Russian Academy of Sciences, Kola Science Centre, Apatity, Russian Federation \\ *t.belogurova@ksc.ru
}

(recibido/received: 22-enero-2021; aceptado/accepted: 15-abril-2021)

\begin{abstract}
The utilization of unconventional technogenic raw materials in producing construction materials is a topical economic and environmental issue. The issue's resolution is impeded by the fact that the overburden rocks of apatite nepheline deposits contain nepheline classified as a deleterious impurity for concrete aggregates under the current standards. This paper is aimed to conduct specialized tests of rocks, aggregates, and concretes for evaluating the corrosion resistance of these materials in water and acid media. The work involved using physical mechanical techniques as well as light and scanning microscopy. It is scientifically validated that nepheline aggregate included in concrete and behaving actively as related to calcium hydroxide produces a denser area of contact with the cement matrix, which favors an enhanced corrosion resistance of concrete. The paper's information is scientifically and practically valuable for resolving the issue with recycling the mining waste of apatite nepheline deposits and utilizing their overburden rocks as concrete aggregates.
\end{abstract}

Keywords: Nepheline-containing rocks, Concrete, Active aggregate, Microscopic research, Cementaggregate interface.

\section{RESUMEN}

El uso de tipos no tradicionales de materias primas artificiales en la producción de materiales de construcción es un problema económico y ambiental relevante. El obstáculo para resolver el problema es que en la composición de las sobrecargas apatitonefelinas de los depósitos contiene nefelina, que según los estándares actuales es una impureza nociva para los agregados de los hormigones. El objetivo del trabajo es realizar estudios especiales de rocas, agregados y hormigones que permitan evaluar la resistencia de estos materiales a la corrosión en ambientes acuáticos y ácidos. El trabajo utilizó métodos de investigación físico-mecánicos, así como técnicas de microscopía de luz y barrido. Está científicamente justificado que el agregado de nefelina en la composición del hormigón, siendo activo en relación con el hidróxido de calcio, proporciona una zona de contacto más densa con la matriz de cemento, lo que contribuye al aumento de la resistencia a la corrosión de hormigones. Los materiales del artículo son de valor científico y práctico para resolver el problema de la eliminación de los desechos mineros de los depósitos de apatitonefelina y el uso de sus sobrecargas de extracción como agregados de hormigones.

Palabras claves: Rocas que contienen nefelina; Hormigones; Agregado activo; Estudios microscópicos; Interface cemento-agregado. 


\section{INTRODUCTION}

Nowadays, there is no doubt in the negative environmental effects of storing mining and smelting waste. At the same time, technogenic raw materials, the main kind of which used in the Kola Peninsula is overburden rocks, can be used in producing construction materials and crushed rock in particular (Kalinkin \& Belogurova, 2019). The use of technogenic waste in recycling is especially relevant within the framework of the global trend for the sustainable development of the mining sector (Gorman \& Dzombak, 2018; Ranängen \& Lindman, 2017; Aznar-Sánchez et al., 2018; Ruokonen \& Temmes, 2019), in particular, from the standpoint of nature conservation (Yadav \& Samadder, 2017; García-González et al., 2014; Rada, 2009).

The enterprises of the Kola mining system manufacture more than $60 \%$ of the region's industrial products and are the main source of waste generation. The almost unused overburden rocks of the ore mines of AO Apatite are an example of unsustainable nature management. The amount of waste accumulated as refinement tailings, overburden rocks, and off-balance ore over the ninety years of developing the Khibin apatite-nepheline ore deposits exceeds three billion tonnes (Cadaster, 2019). AO Apatite has nine technogenic deposits on the current books and records. These deposits are quite difficult to maintain and generate a heavy economic burden on the apatite concentrate cost. This is why, it is extremely important to increase the volume of using secondary raw materials from technogenic deposits in comparison with the currently used volume of mere 3-4\%. This issue has recently attracted particular attention (Guryev, 2017; Arkhipov \& Reshetnyak, 2017; Abrashitov, 2019). One of the potential areas of using apatite nepheline ore recycling waste is the production of crushed rock and concrete based on the overburden rocks of AO Apatite (Makarov et al., 2003; Belogurova \& Krasheninnikova, 2004).

These rocks are represented by varieties of nepheline syenites, such as urtites, rischorrites, ijolites, where nepheline is the main mineral. According to the effective standards, nepheline is classified as nonresistant to water media and acids and referred to deleterious impurities for concrete fillers (Standards Russian Federation, GOST 8267-93). This is why, the evaluation of the possibility of using nepheline-containing raw materials as concrete fillers requires ad-hoc research.

The strength and long life of concrete are largely defined by the quality of set cement-aggregate contacts. The possibility of using unconventional active aggregates in concretes of various purposes has been confirmed by a lot of researchers. However, the information about applying nepheline-containing aggregates in concrete is still understudied and considered only by specific examples, mainly in the works of the researchers from the Shukhov Belgorod State Technical University Sh. M. Rakhimbaev, N. M.Tolygina, E. N. Khakhaleva, and others (Topypina, 2016; Khakhaleva et al., 2016; Tolypina et al., 2018). These authors have proved that urtite aggregate improves the corrosion resistance of concrete in acid media as compared with the concrete on quartzy sand.

This paper exposes the studies of the behaviour of urtites, urtite crushed rock, and the derived concretes in various aggressive environments. According to these studies, urtites and urtite crushed rock show a fairly high resistance in liquid aggressive media with an increased content of such ions, as CI-, SO42-, and NO3-. It is scientifically validated that nepheline-containing aggregate as chemically related to calcium hydroxide create a denser cement-aggregate interface and thus prevents concrete from corroding. It is shown that it is expedient to use nepheline-containing aggregates in heavy concretes used in aggressive environments found in the humid conditions of subterranean mines or sewage. The test results allow including overburden rocks of apatite-nepheline deposits in manufacturing processes and resolve the issue with providing the construction industry with HQ nonore materials. 


\section{MATERIALS AND METHODS}

The tests were conducted on the most typical overburden rocks formed with the extraction of apatitenepheline urtite ores at the Vostochny ore mine of the Koashva deposit.

The urtites, urtite aggregates, and concretes were tested for corrosion resistance by direct placement to aggressive liquid media The aggression indicators for the lab media were chosen proceeding from the data on the chemical composition of the ore waters with a hundredfold increase in the concentration of specific most aggressive chemical elements: the media were chlorine with a concentration of CI- ions of $150 \mathrm{mg} / \mathrm{l}$ (medium II - CI-), sulphate with a concentration of SO42- ions of $1500 \mathrm{mg} / \mathrm{l}$ (medium III - SO42-), and nitric with a concentration of NO3- ions of $3500 \mathrm{mg} / \mathrm{l}$ (medium IV - NO3-). The nonaggressive medium was distilled water (medium I $-\mathrm{d}$. w.). To maintain the initial concentration, the solutions were replaced every 30 days.

The corrosion resistance tests of the urtites for determining their weight loss were conducted on cubic samples with 40-mm ribs cut out from a lump material. The changes in weight were controlled by weighing the samples every half a year and comparing the measured weights with the initial weight in water-saturated condition. The strength tests were conducted on cubic urtite samples with 25 -mm ribs. Before the test were begun, the batch of 20 urtite samples was tested for compression strength in watersaturated condition on a P-125 hydraulic press machine. The essence of the test method consisted in comparing every half a year the strength of the samples placed for two years in four different liquid media with their initial strength.

The urtite aggregates were tested for corrosion resistance under the influence of the four above indicated media on crushed rock fines of 10-20 mm. The losses in weight were defined by placing into each medium five samples with an initial dry weight of about $400 \mathrm{~g}$; the samples were then weighed every half a year after being tossed on a sieve with 10-mm cells and then dried to constant weight. Then those samples were left in the same medium until the following test. The crushed rock sample crushability (weight losses in crushed rock squeezed in the cylinder) was defined under GOST 8269.0-97 «Crushed Stone and Gravel of Dense Rock and Industrial Waste for Construction Works. Physical Mechanical Test Methods» in a cylinder of $75 \mathrm{~mm}$ in diameter. The initial crushability values of the urtite crushed rock were found as the average value from six parallel tests. The changes in the crushed stone crushability over the two years were defined by placing $25500 \mathrm{~g}$ urtite crushed stone samples in each lab medium (five parallel tests for each storage life).

The corrosion resistance of the concretes was analyzed on $2 \times 2 \times 10 \mathrm{~cm}$ sample beams. The samples were made from CEM I $52.5 \mathrm{~N}$ cement (Sterlitamak). The 0 to $5 \mathrm{~mm}$ fragmenting chippings of the urtite from the Vostochny ore mine (URT) were used as aggregates for fine-grain concrete. The comparative experiments were conducted using the conventional aggregates from 0 to $5 \mathrm{~mm}$ crushing chippings of granite from the Kuzreka deposit (GR) and the natural sand from the Big Lavna pit with Мкр=2.3 (SND). The ash from the Apatity CHP Plant was used in a fraction of $15 \%$ of the weight of cement for replacing it in the compositions based on urtite (URTASH) and granite (GRASH) (Makarov et al., 1991).

The fine-grained concrete formula accepted for ensuring a consistent procedure of making concrete samples on all of the aggregates had a cement/aggregate ratio of 1:3 at a water/cement ratio of 0.4 . The rock and sand fragmenting chippings used in the works had a coarseness of grading of (2.5-5):(0-2.5) = $2: 1$. The Glenium 51 plasticizer in a fraction of $0.5 \%$ of the cement weight was used in preparing the mixtures for ensuring better placeability, evenly distributing the aggregates across the volume at a water/cement ratio of 0.4 and making the concrete stronger. 
One hundred and forty beams were made for each kind of aggregates; half of the the beams were exposed to steam curing (STC) as follows: a four-hour ageing treatment, a four-hour rise in temperature, an eighthour steam treatment at $80-85^{\circ} \mathrm{C}$, natural cooldown; the other half was hardened in normal mode (NH) at $18-20^{\circ} \mathrm{C}$ and a humidity of $80-90 \%$. All of the samples were put for 28 days into a moisture chamber before being placed into the agressive media.

The corrosion resistance of the concretes in various aggresive media was defined by appearance, weight, compression strength, and bending tensile strength.

The weight levels were defined for constant samples, with five such samples of each varied-hardening composition for each medium. The samples exposed to tensile bending strength and compression strength tests were 10 (5 NG+5 THPR) and 20 in number, respectively, for a concrete composition from each medium. The average initial strength of the concretes of each composition was defined at various bending and compression solidification levels against the values for 20 and 40 samples, respectively, and used as the control strength in the subsequent tests.

\section{RESULTS AND DISCUSSION}

\subsection{Analyzing Corrosion Resistance of Urtites and Urtite-Based Aggregates in Various Aggressive Media}

For the results of the weight changes in the urtite samples tested in the aggressive lab media see Table 1.

Table 1. Changes in the weight of the urtite samples

\begin{tabular}{cccccccc}
\hline \multirow{2}{*}{$\begin{array}{c}\text { Medium } \\
\text { no. }\end{array}$} & \multicolumn{3}{c}{ Average urtite weight values } & \multicolumn{2}{c}{ Weight losses } \\
\cline { 2 - 8 } & $\mathrm{m}_{0}, \mathrm{~g}$ & $\mathrm{~m}_{0.5}, \mathrm{~g}$ & $\mathrm{~m}_{1.0}, \mathrm{~g}$ & $\mathrm{~m}_{1.5}, \mathrm{~g}$ & $\mathrm{~m}_{2.0}, \mathrm{~g}$ & $\Delta \mathrm{m}_{2.0}, \mathrm{~g}$ & $\Delta \mathrm{m}_{2.0}, \%$ \\
\hline $\mathrm{I}-$ & & & & & & & \\
distilled & 188.80 & 188.75 & 188.73 & 188.68 & 188.65 & 0.15 & 0.08 \\
water & & & & & & & \\
$\mathrm{II}-\mathrm{Cl}^{-}$ & 191.13 & 191.06 & 191.00 & 190.95 & 190.90 & 0.23 & 0.12 \\
$\mathrm{III}-\mathrm{SO}_{4}{ }^{2-}$ & 196.30 & 196.23 & 196.21 & 196.15 & 196.10 & 0.20 & 0.10 \\
$\mathrm{IV}-\mathrm{NO}_{3}^{-}$ & 188.52 & 188.43 & 188.40 & 188.35 & 188.31 & 0.21 & 0.11 \\
\hline
\end{tabular}

These results show that a minor reduction in weight was observed every half a year in the samples in all of the liquid media, distilled water included. The maximal weight losses in the cubic urtite samples for two years were $0.12 \%$ in the chlorine medium and did not exceed the allowed $0.15 \%$.

For the results of measuring the strength of the urtite samples tested in the aggressive lab media see Table 2. Before the measurement the batch of samples was tested for compression strength in water-saturated condition. The control strength value of the urtite based on measuring twenty samples was R0 $=150 \mathrm{MPa}$. According to the strength tests, a minor reduction in strength over the two years of testing was observed in the urtite samples in all of the liquid media. The greatest and the lowest reduction was observed in the urtite samples placed in the nitric medium $(12.7 \%)$ and distilled water $(8 \%)$, respectively. The reduction in the stone rock sample strength is characterized by the softening coefficient calculated as Ksoften. $=$ Rpost-test cpr./Rpre-test cpr. At Ksoften. $<0.8$ subsurface rock is considered nonresistant to the operational environment in question. The maximal strength reduction during the test was observed at rock softening coefficient Ksoften. $=0.87$ against acceptable Ksoften. $=0.8$, which allows classifying urtites as 
sufficiently resistant to aggressive liquid media. There were no visual signs of destruction registered in the samples in any of the media.

Table 2. Changes in the strength of the urtite samples

\begin{tabular}{cccccc|ccc}
\hline \multirow{5}{*}{ Medium no. } & \multicolumn{5}{c|}{ Average urtite strength values } & \multicolumn{2}{c}{ Strength losses } & Softening \\
& $\mathrm{R}_{0}, \mathrm{MPa}$ & $\begin{array}{c}\mathrm{R}_{0.5}, \\
\mathrm{MPa}\end{array}$ & $\begin{array}{c}\mathrm{R}_{1.0}, \\
\mathrm{MPa}\end{array}$ & $\begin{array}{c}\mathrm{R}_{1.5}, \\
\mathrm{MPa}\end{array}$ & $\begin{array}{c}\mathrm{R}_{2.0}, \\
\mathrm{MPa}\end{array}$ & $\begin{array}{c}\Delta \mathrm{R}_{2.0}, \\
\mathrm{MPa}\end{array}$ & $\Delta \mathrm{R}_{2.0}, \%$ & coefficient 2.0 \\
\hline $\begin{array}{c}\text { I - distilled } \\
\text { water }\end{array}$ & 150 & 144 & 142 & 141 & 138 & 12 & 8.0 & 0.92 \\
$\mathrm{II}-\mathrm{Cl}^{-}$ & 150 & 142 & 139 & 135 & 132 & 18 & 12.0 & 0.88 \\
$\mathrm{III}-\mathrm{SO}_{4}{ }^{2-}$ & 150 & 141 & 140 & 136 & 134 & 16 & 10.7 & 0.89 \\
$\mathrm{IV}-\mathrm{NO}_{3}^{-}$ & 150 & 141 & 137 & 135 & 131 & 19 & 12.7 & 0.87 \\
\hline
\end{tabular}

In the microstructural analysis of the urtites exposed to aggressive media the emphasis was placed on the shape of the nepheline boundaries and manifestations of reaction. For example, see Figure 1 with several pictures of nepheline - the main mineral in urtites - made before and after the exposure to hydrochloric acid (medium II - CI-) for 1.5 years.
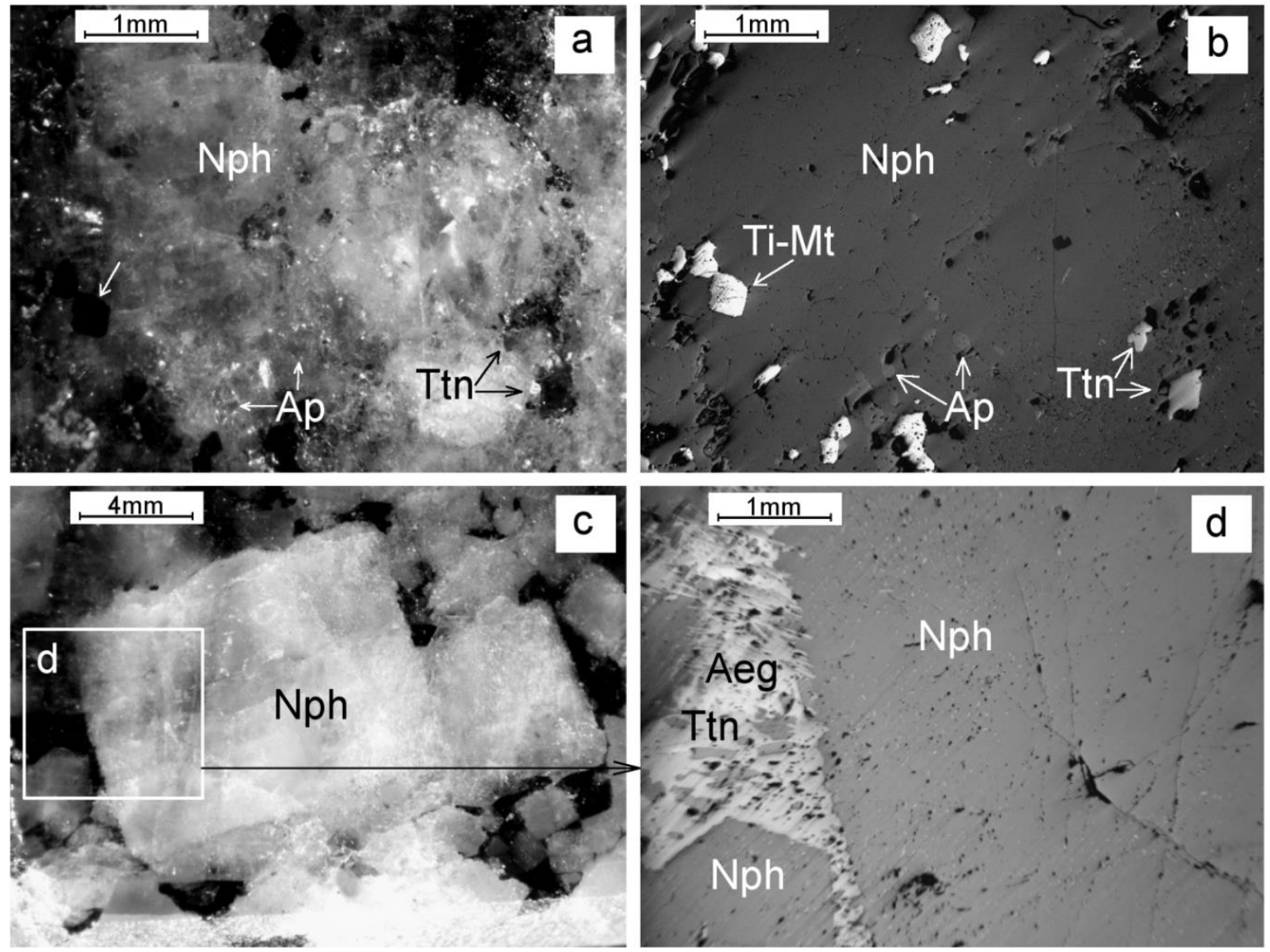

Figure 1. Nepheline (Nph) before exposure to reagents (A-B) and on exposure to hydrochloric acid solution (C-D). $\mathrm{a}$ and $\mathrm{c}$ are macroscale pictures; $\mathrm{b}$ and $\mathrm{d}$ are the pictures in reflected polarized light (Axioplan-2).

Aeg is aegirite; Ap is apatite; Ti-Mt is titanium magnetite; Ttn is titanite 
It is seen under the microscope that the precipitates of the original nepheline are shaped mainly as idiomorphic, followed by rare occurrences of xenomorphic crystals and clusters of nepheline. The mineral is saturated with bird-shot concretions of aeregite, apatite, and titanite. The analysis of the nepheline exposed to hydrochloric acid solution has not revealed any major differences from its original shape. For example, see Fig. 1 (C-D) for a crystal of nepheline exposed to hydrochloric acid. The shear surface is fairly smooth, and its minor porosity may stem from polishing defects. The boundaries with the other minerals are clearly marked; the boundaries and the cracks in the nepheline show no signs of corrosion or secondary mineral formation. A similar behaviour is observed in the nepheline and the rock-shaping minerals in the samples made from urtites exposed to the other liquid media (Belogurova et al.,2019). Thus, as seen from the microscopic examinations, the urtite samples stored in aggressive media show no signs of corrosion. On the whole, as shown by the tests of the urtite samples in liquid media, these rocks are sufficiently resistant to all of the liquid media used.

As shown by the weight changes in the urtite crushed rock tested in aggressive lab media, certain losses in the weight of the test samples of crushed rock were observed after two years of testing. The most aggressive medium for these fillers is nitric, where the losses were $0.51 \%$ against the allowed $5 \%$. Compared with the figures obtained for the parallel samples in distilled water, the weight losses in aggressive media differed by no more than $0.17 \%$. The results reveal that urtite crushed rock shows enough resistance in the examined liquid media.

As determined by analyzing the results of the crushability changes in the urtite crushed rock after the tests in the aggressive media, the crushability increased in all of the media and reached its maximal level of 19.18 in nitric medium. The crushability of the crushed rock samples in distilled water did not differ from the crushability of the samples from the other aggressive media by more than $4.8 \%$. On the whole, the crush rock crushability is compliant with the same grade by strength as before the tests (M1000). It can therefore be concluded that urtite crushed rock is resistant in all of the liquid media.

\subsection{Corrosion Resistance of Concrete in Aggressive Media}

For the results of the half-, one- and two-year bending strength tests of the normal-hardened (NH) and thermally processed (THPR) concrete samples placed in various liquid lab media see Table 3.

As shown by the data analysis, all of the concrete samples had their bending strength increased after half a year of testing. After one year of testing some of the concrete samples had their strength decreased as compared with the results of the first six months. After two years of testing the strength of the samples relative to the results of the first year followed both, an upward and a downward trend. However, the strength of absolutely all of the concrete samples in all of the media exceeded the initial levels.

Table 3. Bending strength of the concrete samples, MPa

\begin{tabular}{|c|c|c|c|c|c|c|c|c|c|c|c|}
\hline \multirow[b]{3}{*}{ Medium } & \multirow{3}{*}{$\begin{array}{c}\text { Test } \\
\text { period }\end{array}$} & \multicolumn{10}{|c|}{ Compositions*, hardening conditions } \\
\hline & & \multicolumn{2}{|c|}{ URT } & \multicolumn{2}{|c|}{ URTASH } & \multicolumn{2}{|c|}{ GR } & \multicolumn{2}{|c|}{ GRASH } & \multicolumn{2}{|c|}{ SND } \\
\hline & & $\mathrm{NH}$ & $\begin{array}{c}\text { THP } \\
\text { R }\end{array}$ & $\mathrm{NH}$ & $\begin{array}{c}\text { THP } \\
\text { R }\end{array}$ & $\mathrm{NH}$ & $\begin{array}{c}\text { THP } \\
\text { R }\end{array}$ & $\mathrm{NH}$ & $\begin{array}{c}\text { THP } \\
\text { R }\end{array}$ & $\mathrm{NH}$ & THPR \\
\hline & pre-test & 8.3 & 9.0 & 8.5 & 9.4 & 7.2 & 8.1 & 7.9 & 8.8 & 6.9 & 8.4 \\
\hline $\mathrm{I}-$ & $0.5 \mathrm{yr}$ & 10.5 & 11.7 & 11.7 & 10.9 & 9.7 & 9.4 & 8.2 & 9.0 & 9.1 & 10.3 \\
\hline distilled & $1 \mathrm{yr}$ & 12.2 & 10.8 & 10.3 & 9.8 & 10.1 & 8.9 & 8.6 & 9.3 & 8.3 & 9.2 \\
\hline water & $2 \mathrm{yrs}$ & 11.6 & 11.2 & 9.8 & 10.2 & 9.7 & 8.8 & 9.7 & 9.1 & 7.8 & 8.6 \\
\hline
\end{tabular}




\begin{tabular}{cccccccccccc}
\hline & $0.5 \mathrm{yr}$ & 9.1 & 9.7 & 10.2 & 11.4 & 10.4 & 9.2 & 8.4 & 9.5 & 10.3 & 9.8 \\
$\mathrm{II}-\mathrm{Cl}^{-}$ & $1 \mathrm{yr}$ & 10.8 & 9.5 & 11.2 & 10.1 & 9.5 & 9.4 & 8.7 & 10.5 & 9.6 & 8.6 \\
& $2 \mathrm{yrs}$ & 10.3 & 9.8 & 10.8 & 10.6 & 8.8 & 9.0 & 8.9 & 9.8 & 8.4 & 8.7 \\
$\mathrm{III}-$ & $0.5 \mathrm{yr}$ & 8.3 & 9.5 & 9.4 & 10.8 & 9.6 & 8.8 & 9.3 & 8.4 & 8.8 & 8.9 \\
$\mathrm{SO}_{4}{ }^{2-}$ & $1 \mathrm{yr}$ & 8.6 & 9.9 & 9.8 & 10.5 & 9.0 & 8.9 & 9.2 & 8.9 & 7.6 & 8.7 \\
& $2 \mathrm{yrs}$ & 8.9 & 10.2 & 9.9 & 10.0 & 9.2 & 9.1 & 9.7 & 9.3 & 8.1 & 8.6 \\
$\mathrm{IV}-$ & $0.5 \mathrm{yr}$ & 11.1 & 10.7 & 9.6 & 10.3 & 9.2 & 9.5 & 10.1 & 9.4 & 8.1 & 9.1 \\
$\mathrm{NO}_{3}^{-}$ & $1 \mathrm{yr}$ & 9.5 & 9.9 & 9.1 & 9.9 & 8.9 & 9.7 & 9.8 & 9.3 & 8.3 & 8.6 \\
& $2 \mathrm{yrs}$ & 9.8 & 10.1 & 9.4 & 10.2 & 9.1 & 9.3 & 9.5 & 9.0 & 7.9 & 8.7 \\
\hline
\end{tabular}

*Compositions: URT is concrete on urtite; URTASH is concrete of urtite with ash; G is concrete on granite; GRASH is concrete on granite with ash; SND is concrete on sand

For the results of the compression strength tests of the same concrete samples see Table 4.

The results of the compression strength tests of the samples after 6,12 , and 24 months of exposure to aggressive media show the same trend as the results of the bending strength tests. For example, it was already in the first half a year when the strength of the concrete on all of the fillers increased by 1.8 to $21.9 \%$ on average. In the subsequent period of storage in the liquid media some of the samples still had their strength increased, whereas the strength of the other samples decreased as compared with the figures after half a year and one year of testing. On the whole, after two years of exposure to aggressive media none of the batches of concrete had its strength decreased; on the contrary, their strength increased by 1.4 to $10 \%$ on average. The addition of ash and thermal processing make the concretes stronger, especially the ones with urtite aggregate.

Table 4. Compression strength of the concrete samples, MPa

\begin{tabular}{|c|c|c|c|c|c|c|c|c|c|c|c|}
\hline \multirow[b]{3}{*}{ Medium } & \multirow{3}{*}{$\begin{array}{c}\text { Test } \\
\text { period }\end{array}$} & \multicolumn{10}{|c|}{ Composition, hardening conditions } \\
\hline & & \multicolumn{2}{|c|}{ URT } & \multicolumn{2}{|c|}{ URTASH } & \multicolumn{2}{|c|}{ GR } & \multicolumn{2}{|c|}{ GRASH } & \multicolumn{2}{|c|}{ SND } \\
\hline & & $\mathrm{NH}$ & $\begin{array}{c}\text { THP } \\
\text { R }\end{array}$ & $\mathrm{NH}$ & $\begin{array}{c}\text { THP } \\
\text { R }\end{array}$ & $\mathrm{NH}$ & $\begin{array}{c}\text { THP } \\
\text { R }\end{array}$ & $\mathrm{NH}$ & $\begin{array}{c}\text { THP } \\
\text { R }\end{array}$ & $\mathrm{NH}$ & THPR \\
\hline & pre-test & 62.6 & 63.8 & 69.7 & 73.3 & 58.8 & 63.2 & 64.4 & 66.2 & 58.9 & 60.2 \\
\hline \multirow{4}{*}{$\begin{array}{c}\mathrm{I}- \\
\text { distilled } \\
\text { water }\end{array}$} & $0.5 \mathrm{yr}$ & 70.2 & 74.2 & 75.2 & 76.5 & 67.4 & 68.5 & 68.2 & 73.8 & 69.6 & 72.4 \\
\hline & $1 \mathrm{yr}$ & 66.1 & 69.2 & 72.8 & 73.5 & 63.4 & 67.4 & 69.8 & 69.9 & 65.1 & 66.1 \\
\hline & $2 \mathrm{yrs}$ & 65.9 & 67.6 & 74.1 & 75.9 & 62.8 & 64.3 & 70.1 & 71.4 & 64.8 & 64.8 \\
\hline & $0.5 \mathrm{yr}$ & 68.8 & 72.3 & 73.8 & 78.8 & 67.9 & 69.6 & 72.8 & 70.9 & 68.6 & 65.3 \\
\hline \multirow[t]{2}{*}{$\mathrm{II}-\mathrm{Cl}^{-}$} & $1 \mathrm{yr}$ & 68.3 & 66.5 & 76.3 & 74.5 & 64.8 & 70.0 & 71.5 & 67.6 & 63.8 & 65.8 \\
\hline & $2 \mathrm{yrs}$ & 66.2 & 65.4 & 72.1 & 74.8 & 62.3 & 64.5 & 65.3 & 68.7 & 60.2 & 63.3 \\
\hline \multirow{3}{*}{$\begin{array}{l}\mathrm{III}- \\
\mathrm{SO}_{4}{ }^{2-}\end{array}$} & $0.5 \mathrm{yr}$ & 63.7 & 69.9 & 71.0 & 75.1 & 62.8 & 67.7 & 69.3 & 74.1 & 71.8 & 68.1 \\
\hline & $1 \mathrm{yr}$ & 62.9 & 64.3 & 73.7 & 74.6 & 62.5 & 66.3 & 68.3 & 75.8 & 69.7 & 66.7 \\
\hline & $2 \mathrm{yrs}$ & 63.5 & 64.9 & 72.3 & 74.9 & 61.9 & 65.1 & 66.6 & 70.1 & 61.3 & 64.9 \\
\hline \multirow{3}{*}{$\begin{array}{l}\mathrm{IV}- \\
\mathrm{NO}_{3}^{-}\end{array}$} & $0.5 \mathrm{yr}$ & 66.4 & 69.6 & 74.3 & 76.1 & 61.7 & 66.8 & 69.1 & 71.7 & 63.7 & 62.9 \\
\hline & $1 \mathrm{yr}$ & 64.8 & 68.7 & 70.1 & 73.6 & 62.3 & 64.1 & 65.8 & 68.7 & 64.5 & 60.3 \\
\hline & $2 \mathrm{yrs}$ & 65.3 & 66.9 & 73.4 & 75.2 & 61.1 & 64.9 & 66.1 & 70.3 & 62.2 & 61.1 \\
\hline
\end{tabular}

As thus determined by the two years of testing, the strength of the concretes on all of the aggregates in all of the liquid media increased at both, compression and bending, which is an undoubted sign of the high corrosion resistance of the tested concretes in the media in question. 
The first thing it is necessary to analyze while studying a new unconventional kind of aggregate for concrete is the physical chemical processes of structuring at the aggregate-cement interface.

As shown by the earlier tests, nepheline interacts at elevated temperatures with the products of clinker portland cement minerals hardening, which results in a structurally stronger nepheline-containing aggregate-cement stone interface (Belogurova, 2005). That said, the newly generated phases produced by the reaction exceed nepheline by volume but are always smaller than the aggregate volume of nepheline and calcium hydroxide, which does not cause any destructive changes in concrete.

As determined by the multiple corrosion resistance tests of aggregates, in certain conditions any aggregate is mechanically or chemically active relative to the calcium hydroxide contained in liquid concrete (Khakhaleva, 2003). As shown by the earlier tests of nepheline-containing rocks, urtites are a more chemically active kind of rock (Belogurova et al., 1990; Krasheninniko \& Belogurova, 2003). Work (Krasheninnikov et al., 1989) studies the influence of the mineral composition of urtite and concrete hardening conditions on the generation of the aggregate-cement matrix interface in concrete and has allowed finding out that the mechanical interaction between the urtite minerals and the binder has decreased as compared with an increase in their chemical interaction.

The structure of concrete was examined on polished concrete samples exposed to liquid media for two years. For the pictures of the concrete samples on urtite and urtite with ash before the tests (28 days of hardening) after and 1.5 years of exposure to nitric acid solution see Fig. 2.

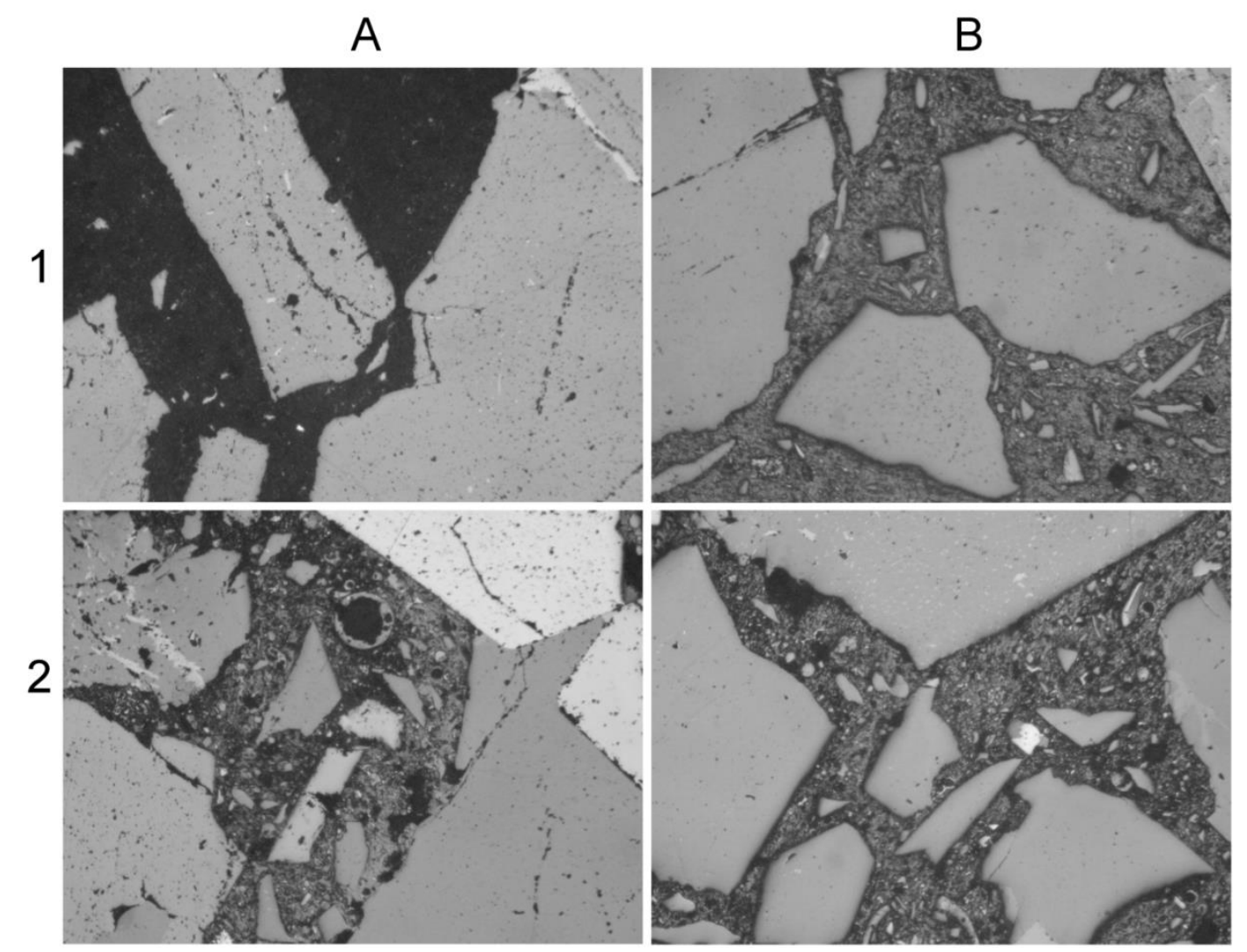

Figure 2. Interface of mineral grains and rock (light) in cement mass (black) in the concrete samples before the tests (A) and after 18 months of exposure to nitric acid (B). The field size is $1.6 \mathrm{~m}$. The pictures were made in reflected light on an UltraPhot-3 miscoscope. A1 is URT-28, A2 is URTASH-28, B1 is URT-1.5-NO3, B2 is URTASH-1.5NO3 
As determined by the microscopic analyses of the concrete structure, all of the presented samples have a dense structure with a strongly marked aggregate-cement contact. In the pictures we clearly see the polymineral structure of urtite, including nepheline, feldspar, titanite, and other minerals. The ash additive is found in the URTASH samples as spheroidal inclusions. It is clearly seen that the additive improves the grindability of the samples (cement stone lightens), that is, the concrete structure becomes stronger, which agrees with the strength test results. In all of the concrete samples stored in nitric acid a so called reaction rim that is indicative of the chemical processes going on in the interface is seen in the aggregate-cement interface (Rakhimbaev et al., 2001). On the whole, the microscopic studies have not revealed any destructive structural changes in any of the samples.

The processes going on in the interface of the concretes were studied using a SEM LEO-420 digital scanning electronic microscope. For the example spallings of the concrete samples on urtite and urtite with ash after 1.5 years of exposure to nitric acid see Fig. 3.

As seen in the pictures, urtite has a firm contact with the cement matrix and this interface is represented by a fine layer of hydrate phase resulting from the interaction of the aggregate surface with calcium hydroxide. The concrete samples have a very developed contact surface covered with neoformations various in composition. For example, the urtite-cement matrix interface has a strongly marked layer of hydrosilicate gel. The mocrographs of the samples with ash show a denser cement-filler interface: there are a lot of neoformations various in composition, ranging from silica gel to spheroidal clusters of hydrosilicate and hydroaluminate compound crystals.
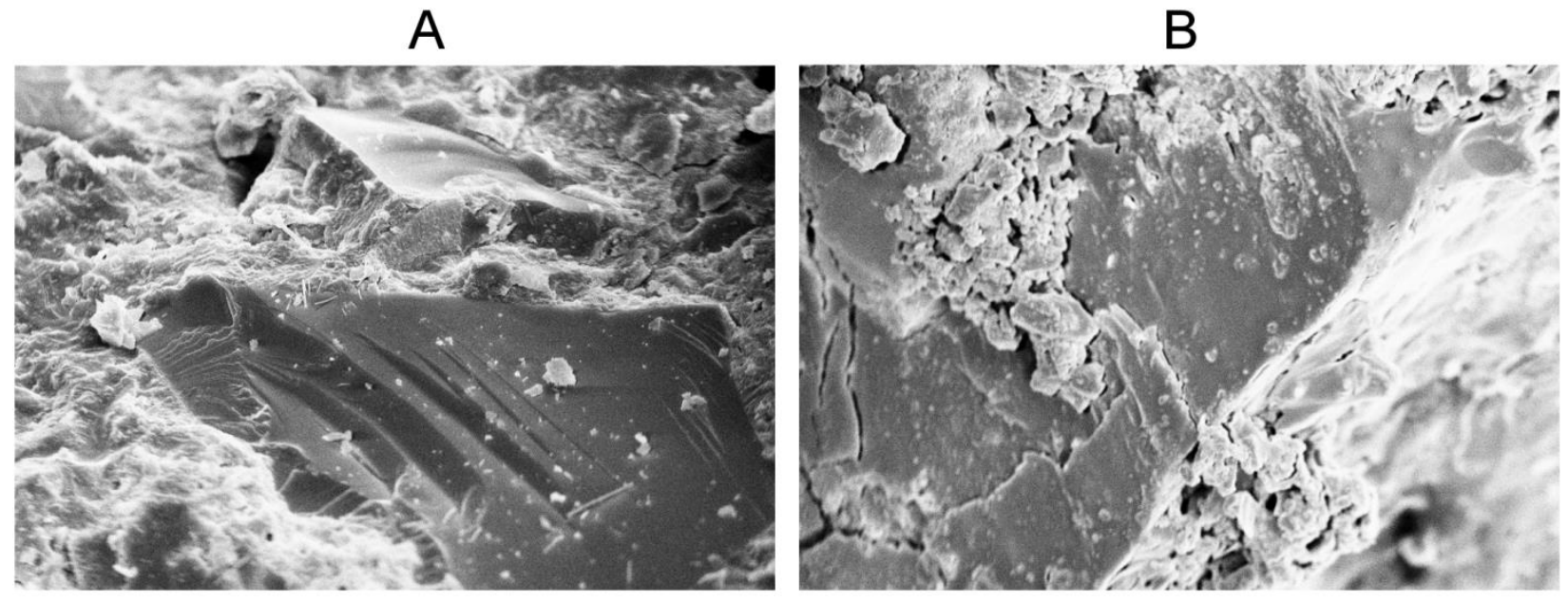

Figure 3. Microstructure of the concrete on urtite and urtite with ash after 18 months of exposure to nitric acid (SEM LEO-420). The amplification is 500. A is URT-1.5-NO3, B is URTASH-1.5-NO3

These neoformations also accumulate in cement pores, filling them and favouring the structural thickening of cement stone. As seen in a high-power Fig. 4A, after 1.5 years of exposure to nitric acid a finely crystalline cellular gel-like hydrate compound structure typical of hydrosilicic acid formed in the pores of the cocrete with urtite aggregate. 
A

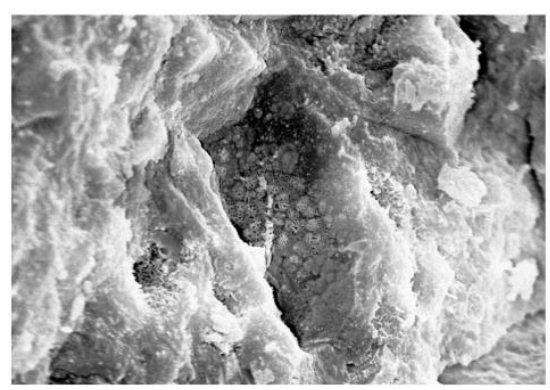

B

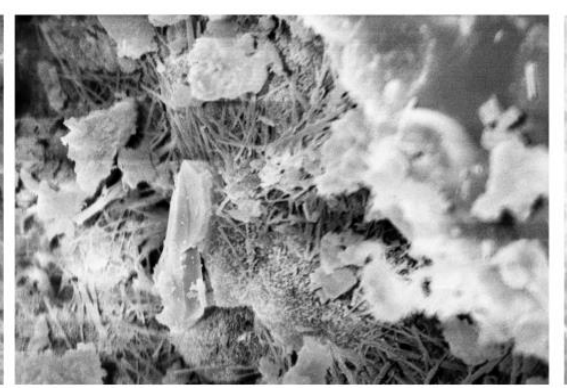

C

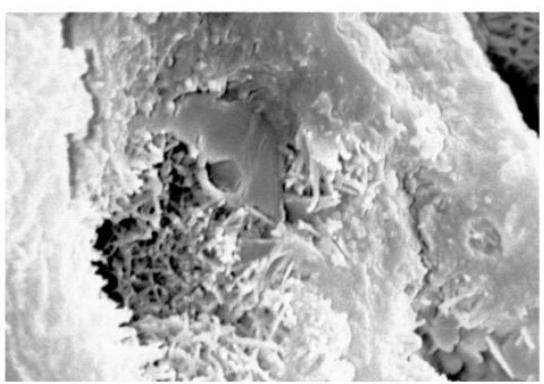

Figure 4. Neoformations in the pores of the concrete on urtite, granite, and sand after 18 months of exposure to nitric acid (SEM LEO-420). The amplification is 2500 (A,B) and 10,000 (C). A is URT-1.5-NO3, B is GR-1.5-NO3, C is

SND-1.5-NO3

Silicic acid is an anhydride of weak orthosilicic acid H4SiO4 that is not aggressive to concrete but has an affined chemical composition. The silicic acid produced by chemical reaction is an acid-resistant substance soluble in fluoric acid only, which makes concretes much better corrosion resistant in acid media.

In Figs. 4B and 4C we clearly see in the cement stone pores fairly large fibrous crystals of hydrosilicates, hydrosulphoaluminates, and other complex calcic salts; these crystals can grow in a focused manner and form textures oriented in a certain way and shaped as acicular spheres or plate crystals or grow chaotically and form feltlike textures. In this case, the cement stone structure is strengthened with the building-in of the pores and an increased adhesion in the concrete's interface. In a chemically aggressive environment this favours the colmatation of the porous space and the aggregate-cement matrix interface of concrete and improves the longevity of the latter (Rakhimbaev, 2012). In addition, the active interaction of acid silicates and alumosilicates with the hydroxyl group plays a positive role in the concrete's internal corrosion processes conditioned by the interaction between alkalies and aggregates.

Thus, as confirmed by the examination of the concrete structure by scanning microscopy, aggressive media intensified the phase formation of secondary products in the examined concrete samples. These neoformations (colmatants) are hardly soluble products of corrosion and precipitate in the cementaggregate interface and in the pores of concrete, which inhibits the diffusion of aggressive agents. It has been established that in terms of the degree of interfaction with the calcium hydroxide of porous fluid in concrete the examined aggregates are active members of the urtite $>$ granite $>$ quartzy sand series.

As shown by the X-ray tests, the hydration products are mainly represented by calcium hydrosilicates like CHS (B), calcium hydroxide, hydrogarnets and hydroaluminates like C4AH13, and calcium carbonate. No nontypical neoformations found in the interface of the tested concretes were discovered. Nor were there any specific effects registered by derivatographic analysis in the examined concrete samples kept in the aggressive environments. The results of the two-year tests under the influence of aggressive media allow concluding that there are no essential differences observed in the test concretes.

\section{CONCLUSIONS}

The studies also allow concluding that not only are there very few structural differences between the concrete with nepheline-containing aggregates in the form of urtites and the concrete with conventional aggregates but also that the improved interface of the concrete with urtite makes it a stronger and denser material. 
The test results show that the concrete with nepheline-containing aggregates have a fairly high resistance, which essentially allows using urtite as concrete fillers.

The test results allow making a significant contribution in resolving the issue with recycling the mining waste of apatite-nepheline deposits and expand the resource potential of nonore constriction materials in the Arctic Zone of Russia

\section{ACKNOWLEDGEMENTS}

We thank D. Manukovskaya from ICT KSC RAS for her assistance in preparing the paper.

\section{CONFLICT OF INTEREST}

The authors declare that they have no conflict of interests.

\section{DATA AVAILABILITY STATEMENT}

Raw data were generated at ICT KCS RAS. Derived data supporting the findings of this study are available from the corresponding author T.P. Belogurova on request.

\section{REFERENCES}

Kalinkin, A. M., \& Belogurova, T. P. (2019). Constructional materials from mining-and-metallurgicalwaste and natural minerals of the Kola Region. Gornyi Journal (Mining Journal), 11, 9-15.

Gorman, M. R., \& Dzombak, D. A.(2018). A review of sustainable mining and resource management: Transitioning from the life cycle of the mine to the life cycle of the mineral. Resources, Conservation \& Recycling, 137, 281-291. https://doi.org/10.1016/j.resconrec.2018.06.001

Ranängen, H., Lindman, Å. (2017). A path towards sustainability for the Nordic mining industry. Journal of Cleaner Production, 151, 43-52. https://doi.org/10.1016/j.jclepro.2017.03.047

Aznar-Sánchez, J. A., García-Gómez, J. J., Velasco-Muñoz, J. F., \& Carretero-Gómez, A. (2018). Mining Waste and Its Sustainable Management. Advances in Worldwide Research. Minerals, 8(7), 284. https://doi.org/10.3390/min8070284

Ruokonen, E., Temmes, A. (2019). The approaches of strategic environmental management used by mining companies in Finland. Resour Conserv Recycl, 210, 466-476. https://doi.org/10.1016/j.jclepro.2018.10.273

Yadav, P., Samadder, S. R. (2017). Assessment of applicability index for better management of municipal solid waste: a case study of Dhanbad, India. Environmental Technol, 39 (12), 1481-1496. https://doi.org/10.1080/09593330.2017.1332104

García-González, J., Rodríguez-Robles, D., Juan-Valdés, A., Morán-del Pozo, J. M., Ignacio Guerra-Romero, M. (2014). Ceramic ware waste as coarse aggregate for structural concrete production. Environmental Technol, 36 (23), 3050-3059. https://doi.org/10.1080/09593330.2014.951076

Rada, E. C., Istrate, I. A., Ragazzi, M. (2009). Trends in the management of residual municipal solid waste. Environmental Technol, 30 (7), 651-661. https://doi.org/10.1080/09593330902852768

State and Prospects of Mining and Smelting Production Waste Formation. In: Kadastr 3.7 Sostoyaniye i perspektivy obrazovaniya otkhodov gorno-metallurgicheskogo proizvodstva OAO Apatit [Kadastr waste mining and metallurgical production Murmansk region. chapter 3.7. OAO Apatite]. Retrieved from: https://www.murman.ru/ecology/cadastre/3-7.html (Access. 25 May 2020) 
Guryev, A. A. (2017). Sustainable Development of Crude Ore Resources and Benefication Facilities of JSC Apatit Based on Best Engineering Solutions. Journal of Mining Institute, $228,662-673$. https://doi.org/10.25515/PMI.2017.6.662

Arkhipov, A. V., \& Reshetnyak, S. P., N. N. Mel'nikov (Sci. Ed.). (2017). Tekhnogennyye mestorozhdeniya. Razrabotka i formirovaniye [Development and Formation of Technogenic Deposits]. KSC RAS, Apatity.

Abrashitov, A. Yu. (2019). Activities of the Kirov Branch of AO Apatit. https://www.phosagro.ru/about/holding_kirovsk (Accesed May 25, 2020)

Belogurova, T. P., Krasheninnikova, O. N. (2004). Utilizatsiya vskryshnykh porod KHibinskikh apatitonefelinovykh mestorozhdeniy v stroitel'stve [Recycling Overburden Rocks of Khibin Apatite Nepheline Deposits in Construction]. Construction Materials, 7, 32-35.

Makarov, V. N., Krasheninnikov, O. N., Gurevich, B. I., et al. (2003). Construction and Engineering Materials from Mineral Raw Materials Mined at Kola Peninsula [Stroitel'nyye i tekhnicheskiye materialy iz mineral'nogo syr'ya Kol'skogo poluostrova]. KSC RAS, Apatity.

Standards Russian Federation (1995). Crushed Stone and Gravel of Solid Rocks for Construction Works. Specifications (GOST 8267-93, 1995). Moscow: Izdatel'stvo standartov.

Tolypina, N. M., Shchigoreva, E. M., Golovin, M. V., \& Shchigorev, D. S. (2018). Application of Aggregates of Nepheline-Bearing Rocks in Increased Corrosion Resistance Concrete. [Russ]. Vestnik SibADI [SibADI Bulletin], 4, 596-605. https://vestnik.sibadi.org/jour/article/view/708

Topypina, N. M. (2016). On Cement Matrix-Filler Interaction [K voprosu o vzaimodeystvii tsementnoy matritsy s zapolnitelyami]. Modern high technologies, 6-1, 81-85.

Khakhaleva, E. N., Rakhimbaev, Sh. M., \& Topypina, N. M. (2016). Enhancing corrosion resistance of concrete structures for industrial enterprises [Povysheniye korrozionnoy stoykosti betonnykh konstruktsiy promyshlennykh predpriyatiy]. Belgorod: BSTU

Makarov, V. N., Bobrova, A. A., Krasheninnikov, O. N., et al. (1991). Physical Chemical Aspects of Bottom-Ash Mixtures for Combined Heat and Power Plants [Fiziko-khimicheskiye aspekty kompleksnogo ispol'zovaniya zoloshlakovykh smesey teplovykh elektrostantsiy]. KSC, Academy of Sciences of the Soviet Union, Apatity

Belogurova, T. P., Neradovskiy, Yu. N., \& Kompanchenko, A. A. (2019). Corrosion Resistance of Urtites in Aggressive Media. In N. E. Kozlov (Ed.), Works of Fersman Science Session of GI KSC RAS. (pp.16, 23-27). https://doi.org/10.31241/FNS.2019.16.005

Belogurova, T. P. (2005). Zapolniteli iz vskryshnykh porod KHibinskikh apatitonefelinovykh mestorozhdeniy i betony na ikh osnove [Aggregates from Overburden Rocks of Khibin Apatite-Nepheline Deposits and Concretes on Their Basis]. (PhD thesis, Kola Science Centre of the Russian Academy of Sciences, Apatity (KSC RAS).

Khakhaleva, E. N. (2003). Vliyaniye vida zapolnitelya na korrozionnuyu stoykost' betona [Influence of Kind of Aggregate on Corrosion Resistance of Concrete]. In E. I. Evtushenko (Gen. Ed.), Modern Technologies in Construction Materials and Construction Industry, International Congress in the Honour of the 150th Anniversary of V. G. Shukhov. Bulletin Belgorod State Technology University,5 (1), 162-164. Belgorod: Odin Mir.

Krasheninnikov, O. N., \& Belogurova, T. P. (2003). Kompleksnoye ispol'zovaniye apatitonefelinovykh rud OAO «Apatit». Chast 2 [Integral Use of Apatite-Nepheline Ores of OAO Apatite Part 2]. In V. N. Makarov (Ed.), Stroitel'nyye $i$ tekhnicheskiye materialy iz mineral'nogo syr'ya Kol'skogo poluostrova [Construction and Engineering Materials from Mineral Raw Materials Mined at Kola Peninsula] (pp. 7-22.). Apatity: KSC RAS

Belogurova, T. P., Krasheninnikov, O. N., Roiak, G. S., et al. (1990). O reaktsionnoy sposobnosti vskryshnykh porod 
rudnikov PO «Apatit» [On Reactive Capability of Overburden Rocks from Ore Mines of PO Apatite]. In V. N. Makarov (Gen. Ed.), Fiziko-khimicheskiye osnovy pererabotki i primeneniya mineral'nogo syr'ya, Apatity [Physical Chemical Basics of Processing and Utilizing Mineral Raw Materials] (pp. 32-35). KSC, Academy of Sciences of the Soviet Union.

Krasheninnikov, O. N., Belogurova, T. P., \& Tsvetkova, T. V. (1989). Vliyaniye mineral'nogo sostava urtitovogo zapolnitelya i usloviy tverdeniya betona na formirovaniye kontaktnoy zony [Influence of Mineral Composition of Urtite Aggregate and Concrete Hardening Conditions on Interface Formation]. In V. N. Makarov (Ed.), Kompleksnoye ispol'zovaniye mineral'nogo syr'ya $\mathrm{v}$ stroitel'nykh i tekhnicheskikh materialakh[Integral Utilization of Mineral Raw Materials in Construction and Engineering Materials] (pp. 22-25). Apatity: KSC, Academy of Sciences of the Soviet Union.

Rakhimbaev, Sh. M., Tolypina, N. M., \& Khakhaleva, E. N. (2001). Proyavleniye effekta aktivnogo zapolnitelya pri korrozii vyshchelachivaniya izvesti iz tsementnogo betona [Manifestation of Active Aggregate Effect with Leaching Corrosion of Lime from Cement Concrete]. In E. I. Evtushenko, Part I of VII Academic Readings of the Russian Academy of Architecture and Construction Sciences «Modern Issues of Construction Materials Science» (pp. 454457).

Rakhimbaev, Sh. M., \& Tolypina, N. M. (2011). Kislotostoykiy beton s effektivnym aktivnym zapolnitelem [AcidResistant Concrete with Efficient Active Aggregate]. Concrete and reinforced concrete, 4, 24-26.

Rakhimbaev, Sh. M. (2012). Kinetika protsessov kol'matatsii pri khimicheskoy korrozii tsementnykh sistem [Kinetics of Colmatation with Chemical Corrosion of Cement Systems]. Concrete and reinforced concrete, 6, 16-17. 